\title{
Study of Groundwater Vulnerability to Contamination in Part of the Klaten District Area, Central Java-Indonesia
}

\author{
Yohana Mariska Puteri Adhesti ${ }^{1}$ and Margaretha Widyastuti ${ }^{1 *}$ \\ ${ }^{1}$ Department of Environmental Geography, Faculty of Geography, Universitas Gadjah Mada, 55281 the Special Region of \\ Yogyakarta, Indonesia
}

\begin{abstract}
Water demands and risks of groundwater pollution in the Klaten District consistently increase as the human population grows over the years. This study aimed to examine the intrinsic and specific groundwater vulnerability levels (low, moderate, high) and analyze the spatial distribution and degree of contribution of the parameters to the vulnerability in some parts of the district area. The data included depth to the water table (measured directly at selected wells), rainfall records in 2009-2019, land-use maps (RBI), 30m DEM (SRTM), geological maps and geoelectric data. Groundwater vulnerability was analyzed with the Susceptibility Index by overlaying five parameters, which according to the results varied across the district: shallow to deep groundwater, aquifers that were composed of sandstone, sand and gravels and rock materials in between, topography of $<2 \%$ and $2-6 \%$ and diverse land-use types from agricultural fields to built-up lands. Most of the research area had moderate intrinsic and specific vulnerability $(43.93 \%$ and $50.53 \%)$, followed by high $(38.24 \%$ and $46.43 \%)$ and low $(17.83 \%$ and $3.04 \%)$. Also, depth to the water table and land use are the most influencing parameters. The results of this study are expected to provide a reference for the government to consider factoring in priority areas based on groundwater vulnerability levels in formulating the district's spatial plan.
\end{abstract}

\section{Introduction}

Water is one of the earth's components essential to support and sustain the life of living organisms. To meet basic daily needs humans extract water from different sources. In some regions groundwater is particularly preferred as it has relatively better quality than other water sources and is easy to reach [1]. However, as population multiplies water demands are expected to increase and more anthropogenic activities are projected to generate waste and introduce pollutants into the groundwater, potentially reducing its quality.

Groundwater vulnerability measures the ease with which pollutants introduced onto the soil surface can reach groundwater tables [2]. It differentiates into two types, namely specific groundwater vulnerability and intrinsic groundwater vulnerability [3]. The former is attributable to physical conditions, such as hydrogeological characteristics that protect groundwater from being polluted, while the latter deals with the absence or presence of a source of pollutants [4].

Klaten District is flanked by two big cities: Surakarta and Yogyakarta that are accelerating urbanisation and development in the area [5]. This has increased and diversified human activities in occupying and utilising land and has created potential sources of environmental pollutants that affect specific groundwater vulnerability.
Agriculture makes one of the activities that dominantly occupy the district and thus contribute to the largest share of groundwater extraction. As stated in the Klaten District Regulation Number 9 of 2012 Article 7, groundwater withdrawal is prioritised for agricultural purposes. However, not a few farming practices in the district use chemical fertilisers excessively [6], causing the groundwater to be more prone to pollution. Furthermore, densely occupied settlements in urban areas and several industrial activities can contaminate this water source. If left untreated, the water quality will deteriorate and not fulfil the need for clean water.

Therefore, it is necessary to assess groundwater vulnerability in the study location. The purpose of this research was to examine the spatial distribution of groundwater vulnerability levels and their parameter sand analyse which parameters contributed the most to the groundwater vulnerability in part of the Klaten District area. The results and findings are expected to assist in groundwater management and treatment to protect and preserve water quantity and quality, sustaining the intended use of groundwater by the community. 


\section{Research location}

The research was conducted in part of the Klaten District, Central Java, covering a $182.67-\mathrm{km}^{2}$ area. It consists of 16 sub-districts: Klaten Utara, Klaten Tengah, Klaten Selatan, Kalikotes, Jatinom, Ngawen, Karanganom, Polanharjo,Ceper, Trucuk, Delanggu, Pedan, Cawas, Karangdowo, Juwiring and Wonosari
(Fig. 1). Astronomically it is located at $7^{\circ} 38^{\prime} 16.41^{\prime \prime}-7^{\circ} 43^{\prime} 55.89^{\prime \prime} \mathrm{S}$ and $110^{\circ} 35^{\prime} 26.58^{\prime \prime}-$ $110^{\circ} 44^{\prime} 55.94 "$ E. Klaten is included in the Karanganyar-Boyololali Groundwater Basin and is one of the districts in the province that is flanked by Merapi Volcano and Seribu Mountains [7]. It is composed of three geological formations: Mandalika Formation (Tomm), Undivided Volcanic Rocks (Qvm) and Alluvium (Qa) [8].



Fig. 1. Map of the study area.

\section{Methods}

\subsection{Susceptibility Index}

The research used the Susceptibility Index (SI), which is a function of the five parameters mentioned below:

1. Depth to the water table (D)

2. Groundwater recharge (R)

3. Aquifer media (A)

4. Topography (T)

5. Land use (LU)

SI is one of the developments of the DRASTIC method and was introduced by Ribeiro [9]. It adds a new parameter, land use (LU), to the equation and thus enables its users to incorporate anthropogenic factors and influences in the calculation [9]. In other words, SI produces specific instead of intrinsic groundwater vulnerability. Furthermore, with the addition of a new weighting system the measured vulnerability is expected to be more precise in characterising the hydrological environment in any case study [10].

These parameters had different weight values and thus different effects. In detail, the weight value of each parameter is presented in Table 1 below [9].
Table 1. The weight values of the Susceptibility Index (SI) parameters.

\begin{tabular}{lcc}
\hline \multicolumn{1}{c}{ Parameters } & Symbols & $\begin{array}{c}\text { Weight } \\
\text { values }\end{array}$ \\
\hline Depth to the water table & $\mathrm{D}$ & 0.186 \\
Groundwater recharge & $\mathrm{R}$ & 0.212 \\
Aquifer media & $\mathrm{A}$ & 0.259 \\
Topography & $\mathrm{T}$ & 0.121 \\
Land use & $\mathrm{LU}$ & 0.222 \\
\hline
\end{tabular}

The above parameters were overlaid in ArcGIS to produce groundwater vulnerability. For the intrinsic vulnerability, the first four parameters were overlaid: depth to the water table, groundwater recharge, aquifer media and slope. As for the specific vulnerability, it combined them with an additional parameter: land use. This process used Eq. 1 to produce an index, which basically sums the multiplication of parameter scores by their respective weight values:

$$
\begin{aligned}
S I=0.186 \mathrm{Dr} & +0.212 R r+0.259 \mathrm{Ar}+0.121 \mathrm{Tr} \\
& +0.222 L U
\end{aligned}
$$

The SI values were statistically grouped into low, moderate or high groundwater vulnerability based on the range and the class interval calculated using Eq. 2 and 3 below:

$$
\text { Range }=X_{\max }-X_{\min }
$$

Class interval $=$ Range $:$ Number of classes 


\subsection{Depth to the Water Table}

Depth to the water table was measured directly in the field (primary data) and then processed in ArcGIS software. The measurement used systematic and grid sampling, which evenly divided the study area into $1 \mathrm{x} 1$ $\mathrm{km}^{2}$ grids, resulting in a sample size of 198 wells. These data were divided into seven classes, each has a range of values and a score, as presented in detail in Table 2 [9].

Table 2. Classification and scores of depths to water table

\begin{tabular}{ccc}
\multicolumn{3}{c}{$(\mathrm{D})}$. \\
\hline No. & Range of values $(\mathbf{m})$ & Scores \\
\hline 1. & $<1.5$ & 100 \\
2. & $1.5-4.6$ & 90 \\
3. & $4.6-9.1$ & 70 \\
4. & $9.1-15.2$ & 50 \\
5. & $15.2-22.9$ & 30 \\
6. & $22.9-30.5$ & 20 \\
7. & $>30.5$ & 10 \\
\hline
\end{tabular}

\subsection{Groundwater recharge (R)}

For groundwater recharge, the research processed rainfall records (secondary data) to obtain the groundwater recharge by factoring in the local geological properties. The groundwater recharge coefficients for different lithological units are presented in Table 3 [11]. Meanwhile, the criteria for rainfall classification are summarised in Table 4 [9].

Table 3. Groundwater recharge coefficients of several geological characteristics.

\begin{tabular}{clc}
\hline No. & \multicolumn{1}{c}{$\begin{array}{c}\text { Lithological } \\
\text { Units }\end{array}$} & $\begin{array}{c}\text { Groundwater } \\
\text { Recharge } \\
\text { Coefficients (\%) }\end{array}$ \\
\hline 1. & $\begin{array}{l}\text { Impervious rocks } \\
\text { 2. }\end{array}$ & $10-20$ \\
2lluvial and & 60 \\
pyroclastic deposits & Lava & 80 \\
4. & $\begin{array}{l}\text { Sandstones - clay - } \\
\text { clay deposits and }\end{array}$ & 20 \\
5. & $\begin{array}{l}\text { limestones } \\
\text { Limestones }\end{array}$ & 90 \\
6. & Pyroclastics & 40 \\
\hline
\end{tabular}

Table 4.Classification and scores of rainfall data as a proxy

\begin{tabular}{ccc}
\multicolumn{3}{c}{ of groundwater recharge $(\mathrm{R})}$. \\
\hline No. & Range of values $(\mathbf{m m})$ & Scores \\
\hline 1. & $<51$ & 10 \\
2. & $51-102$ & 30 \\
3. & $102-178$ & 60 \\
4. & $178-254$ & 80 \\
5. & $>254$ & 90 \\
\hline
\end{tabular}

\subsection{Aquifer media (A)}

Details on the aquifer media were obtained by combining geoelectric measurements results and secondary data. The five measurement points were selected by purposive sampling that took into account the landforms at the study site. The geoelectric measurement results were then compared with the secondary data. Table 5 shows several types of aquifer media and their respective scores for the SI calculation [9].

Table 5.Types and scores of various aquifer media (A).

\begin{tabular}{|c|c|c|}
\hline No. & Types of aquifer media & Scores \\
\hline 1. & Massive shales & 20 \\
\hline 2. & Metamorphic/igneous rocks & 30 \\
\hline 3. & $\begin{array}{l}\text { Metamorphic/weathered igneous } \\
\text { rocks }\end{array}$ & 40 \\
\hline 4. & Glacial deposits & 50 \\
\hline 5. & $\begin{array}{l}\text { Sandstone layers, limestones, shale } \\
\text { layers }\end{array}$ & 60 \\
\hline 6. & Massive sandstones & 60 \\
\hline 7. & Massive limestones & 80 \\
\hline 8. & Sand and gravels & 80 \\
\hline 9. & Basalt & 90 \\
\hline
\end{tabular}

\subsection{Topography (T)}

Topographyswere extracted from 30m DEM data (SRTM, secondary data). The criteria for slope classification in the SI calculation are shown in Table 6 [9].

\begin{tabular}{|c|c|c|}
\hline No. & Classes (\%) & Scores \\
\hline 1. & $<2$ & 100 \\
\hline 2. & $2-6$ & 90 \\
\hline 3. & $6-12$ & 50 \\
\hline 4. & $12-18$ & 30 \\
\hline 5. & $>18$ & 10 \\
\hline
\end{tabular}

\subsection{Land use (LU)}

Land use represents human activities taking place in a defined area. Land-use types and distributions were obtained from the 1:25,000 Indonesian Land-Use Map (RBI,secondary data). As shown in Table 7, each land-use type has a different score in the SI calculation [9].

\begin{tabular}{lc}
\multicolumn{2}{c}{ Table 7. Land use (LU) classification. } \\
\hline \multicolumn{1}{c}{ Types } & Scores \\
\hline \multicolumn{1}{c}{ Agricultural areas } \\
\hline Annual crops, rice fields & 90 \\
Permanent crops & 70 \\
Heterogenous agricultural areas & 50 \\
Pastures and agro-forestry areas & 50 \\
\hline \multicolumn{2}{c}{ Artificial areas } \\
\hline Waste-generating industries, landfills \\
Mines, shipyards, open-pit mines \\
Urban areas, airports, ports, railway \\
stations, industrial and commercial \\
complexes, green open spaces \\
\hline \multicolumn{2}{c}{ Natural areas } \\
\hline Aquatic ecosystems (swamps, \\
lagoons, tidal zones) \\
$\begin{array}{l}\text { Forests and semi-natural zones } \\
\text { Bodies of water }\end{array}$ \\
\hline
\end{tabular}

\subsection{Validation to Nitrate}

This step correlated intrinsic and specific groundwater vulnerability with nitrate concentrations $\left(\mathrm{NO}_{3}\right)$ - a groundwater quality parameter that had previously been processed and analysed from 26 water samples in the laboratory. These samples were selected 
by purposive sampling and examined for their qualities.

\section{Results and discussion \\ 4.1. Depth to the water table}

Depth to the water table determines the length of contact between pollutants and groundwater [12]. The deeper the water table from the surface, the longer it takes for pollutants to reach the groundwater [8]. The measurement results showed that the depth to the water table in the research location varied from $<1.5 \mathrm{~m}$ to $15.2 \mathrm{~m}$. Further, the groundwater was shallow in alluvial plains in the east and became deeper northward (up to $15.2 \mathrm{~m}$ ), as identified in Karanganom and Polanharjo. Both sub-districts had deep groundwater because they are located close to the foot of the volcano and many springs.

\subsection{Groundwater recharge}

Groundwater recharge is the amount of rainwater seeping into the ground [8]. The greater the recharge, the higher the possibility of the groundwater to be contaminated [11]. Based on the analysis, the groundwater recharge in the study area was $>254$ $\mathrm{mm} /$ yearor the highest in the classification for the SI calculation. Thus, there is a high likelihood for the groundwater to be contaminated.

\subsection{Aquifer media}

Aquifer media consists of layers of materials whose hydrogeological properties shape their respective permeability values, which determine the infiltration rate of pollutants [12]. Based on the geoelectric measurements at five points and some secondary data, it was found that the aquifer media of the study site was a dominant layer of sandstone and sand and gravel.

\subsection{Slope}

Based on the analysis results, the area had two slope classes: $<2 \%$ and $2-6 \%$. Areas with low Topography retain runoff water longer, allowing higher infiltration and greater potential for pollution [13].

\subsection{Land use}

Based on the data analysis, more than half of the research location was mainly used for irrigated rice fields $(55.6 \%$ of the total area). This type of land use was distributed evenly, except in the City of Klaten where settlements and industrial buildings were ubiquitous. Settlements were the land use with the second-highest areal percentage. Like the irrigated rice fields, they were scattered in each sub-district, though appearing in a much higher density in urban regions like the City of Klaten. The rest of the research location was used for dry cultivated fields, plantations and industrial and office buildings that form cluster patterns along the main Yogyakarta-Solo Road.

\subsection{Intrinsic groundwater vulnerability}

Based on the parameter overlay results, there are three classes of intrinsic vulnerability: low, moderate and high (Fig. 2). About $17.83 \%$ of the total research area had low vulnerabilities spread in the northern and southern sub-districts:part of Klaten Tengah, Kalikotes, Ngawen, Karanganom, Polanharjo, Ceper and Delanggu. Low vulnerability indicates that pollutants cannot easily contaminate groundwater [14]. Here, it is the combined result of small Topographys (2-6\%), aquifer media in the form of sandstones, groundwater recharge of $>254 \mathrm{~mm} /$ year and shallow to very deep groundwater (depths to water tables $=1.5-15.2 \mathrm{~m}$ ). The deeper the water table from the ground's surface, the longer it takes for pollutants to reach the groundwater [8].

The moderate vulnerability level was identified in $43.93 \%$ of the total research area, distributed in the northern and western sub-districts:a part of Jatinom, Ngawen, Klaten Utara, Klaten Selatan, Klaten Tengah, Kalikotes, Trucuk, Karanganom, Ceper, Pedan, Delanggu, Juwiring and Wonosari. Compared with the low vulnerability, moderate here means that pollutants introduced on the surface can easily reach and contaminate groundwater. It is the combined result of flat slope $(<2 \%)$, aquifer media in the form of sandstones, shallow to medium-deep groundwater (depths to water tables $=1.5-9.1 \mathrm{~m}$ ) and groundwater recharge of $>254 \mathrm{~mm} /$ year. Smaller Topographys and shallower water tables than what characterise low vulnerability have made the regions fall into the category of moderate vulnerability.

High vulnerability covered up to $38.24 \%$ of the research area, particularly in the eastern sub-districts: part of Klaten Selatan, Klaten Utara, Kalikotes, Trucuk, Ceper, Pedan, Cawas, Juwiringand Karangdowo. High vulnerability results from a combination of environmental properties that allow pollutants to seep into the soil and reach groundwater easily. Here, these properties are flat terrains (Topography of $<2 \%$ ) and sand-and-gravel aquifer media. Sand and gravels have good porosity and are excellent media for storing and releasing water [15], facilitating pollutants to enter the aquifer zone much quickly.

\subsection{Specific groundwater vulnerability}

Specific vulnerability adds intrinsic vulnerability parameters with land use to represent waste-generating activities that potentially introduce pollutants to groundwater. There are wide variations between the intrinsic and specific vulnerabilities. The specific groundwater vulnerability map of the research location is shown in Fig. 3. 


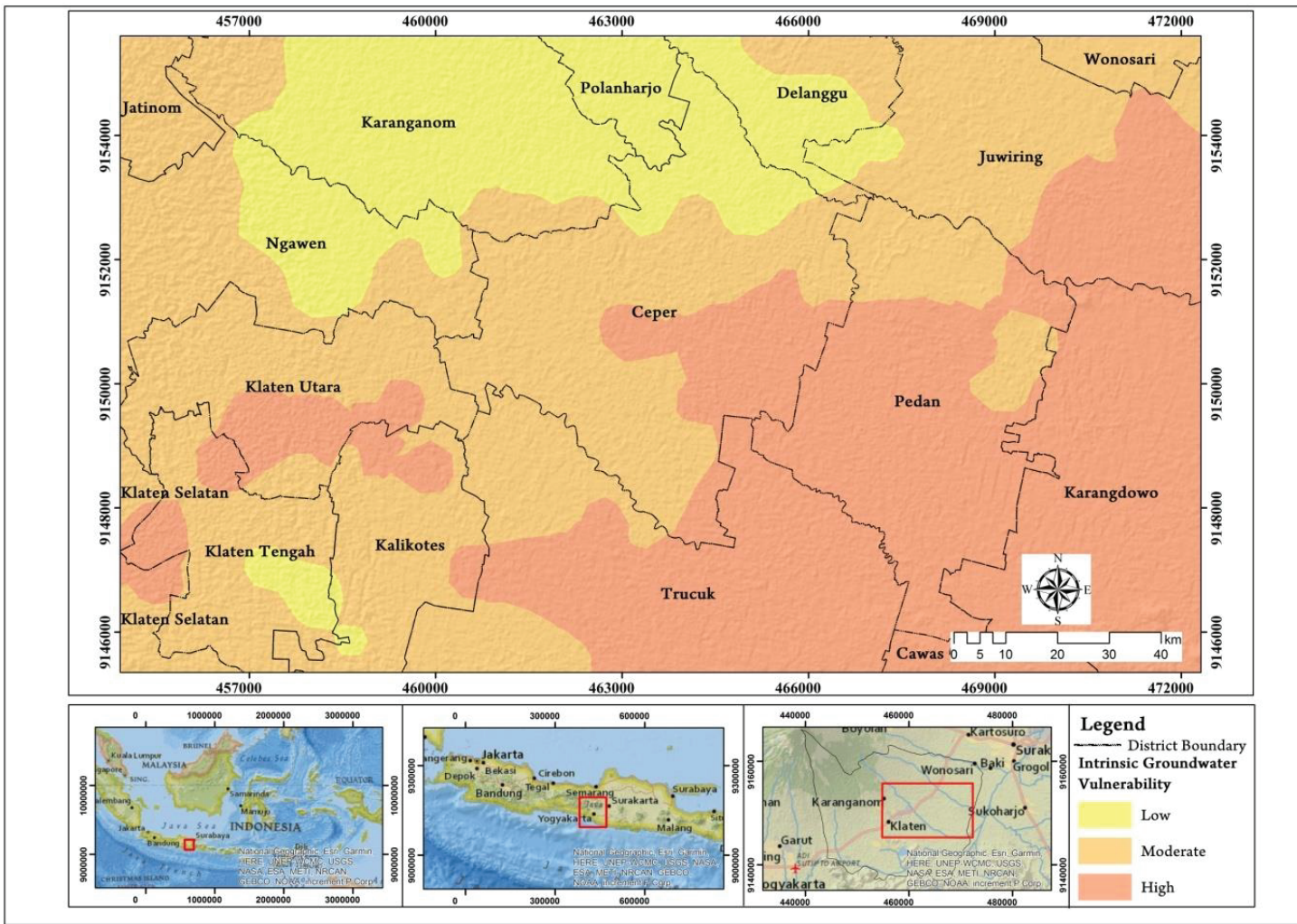

Fig. 2. Map of the intrinsic groundwater vulnerability in part of the Klaten District area.

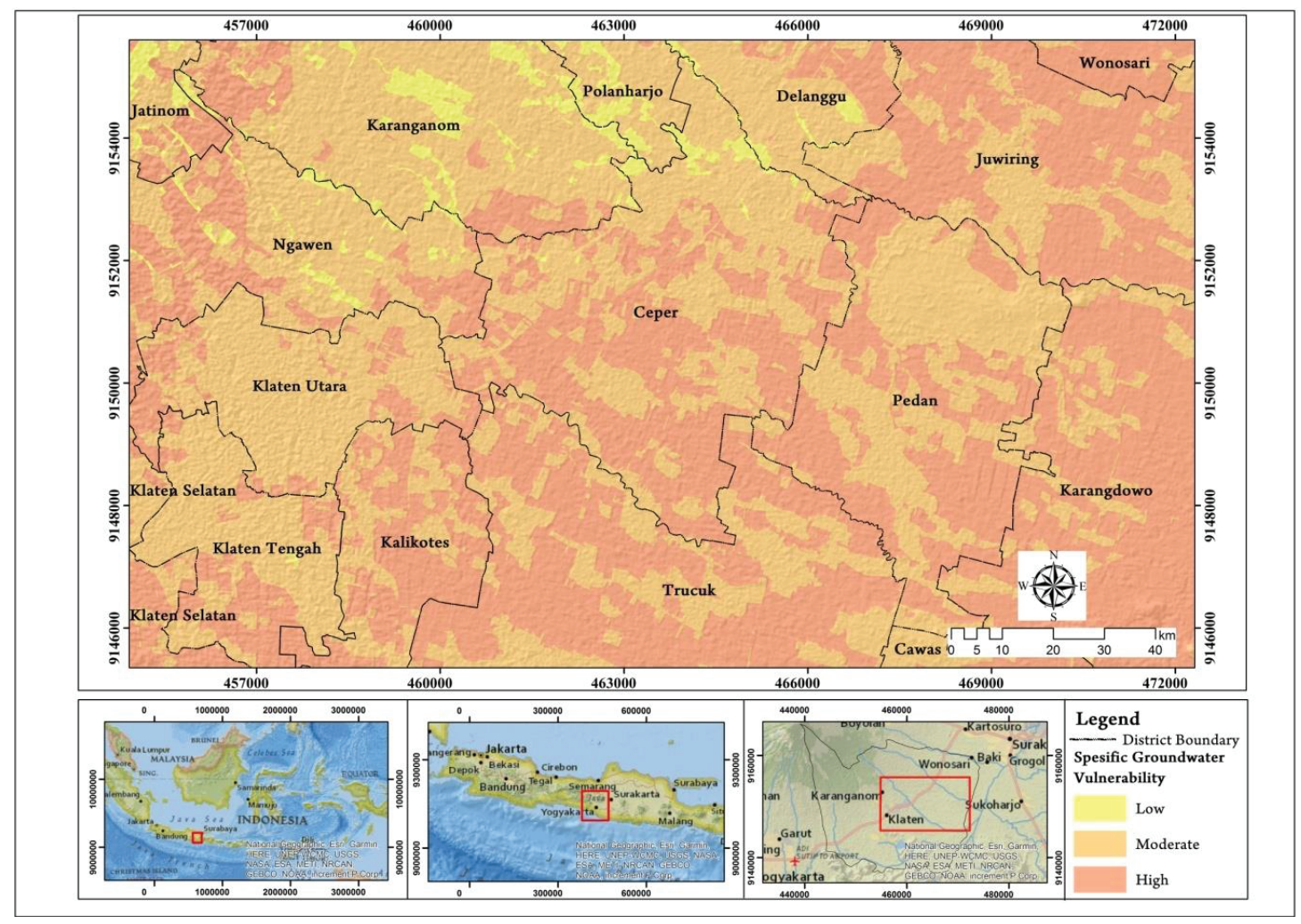

Fig.3. Map of the specific groundwater vulnerability in part of the Klaten District area. 
Sub-districts with moderate vulnerability were located in the west and north, covering $50.53 \%$ of the total research area, including the City of Klaten (Klaten Utara, Klaten Tengah and Klaten Selatan). They are characterised by vast irrigated rice fields, shallow groundwater and an aquifer composed of sandstones. The moderate vulnerability also indicates that the contaminants generated on the surface can likely reach and pollute groundwater. However, over time and with extensive regional development, the sub-districts may develop characteristics that worsen their moderate groundwater vulnerability into high.

The high specific vulnerability covered $46.43 \%$ of the total research area, especially in the eastern subdistricts: Trucuk, Ceper, Juwiring, Wonosari, Pedan and Karangdowo. In these regions irrigated rice fields and settlements were distributed widely and interspersed with industrial, commercial and office buildings, thus potentially generating more waste byproducts than other land-use types. When coupled with level terrains, shallow groundwater and sand-andgravel aquifer, these land-use types create high vulnerability. In this state the groundwater is at higher risk of being polluted compared with moderate and low vulnerability levels.

In contrast to the current study, the SI-based research in the Daule aquifer, Ecuador, presents six vulnerability classes on the resultant map: extremely low, very low, low, moderate, high and very high [9]. Through extensive analysis, it has been found that regions with high vulnerability levels are mainly used for irrigated rice fields and have high groundwater recharge on the alluvial plain. This finding is similar to the current study results in that the high specific groundwater vulnerability in Klaten is attributable to the vast irrigated rice fields and high groundwater recharge. Meanwhile, the moderate and low vulnerabilities in the Daule aquifer coincide with three other land-use types: forests, bodies of water and seminatural areas.

Another study using the SI method has been conducted in the Takelsa aquifer, Northeast Tunisia,in which the groundwater vulnerabilities are presented in four classes: low, moderate, high and very high [16]. Like the current study, most of the Takelsa aquifer $(90 \%)$ is moderately and very highly vulnerable to pollution; only a small part of the recharge area $(10 \%)$ has low vulnerabilities. The high vulnerability is the combined result of level terrains, extensive agricultural land use, high groundwater recharge, sandy soils and shallow depths to water tables. In the current study these factors are also responsible for the high specific groundwater vulnerability in Klaten.

There has also been another study conducted in the alluvial plains of Semarang (Central Java, Indonesia), where the groundwater vulnerability is classified into low, moderate and high [17]. The analysis results have shown that nearly half of the area $(41.3 \%)$ is highly vulnerable to pollution, particularly in the north where ponds, settlements, industries and rice fields are extensive. The high vulnerability results from level slopes, aquifer media composed of sand and shallow groundwater. Meanwhile, more than half of the alluvial plains $(50.3 \%)$ are moderately vulnerable. They are used mainly for settlements and rice fields and have gently sloping terrains, shallow groundwater and aquifers composed of sand. Only a small part of the area $(8.4 \%)$, including the southern regions, has low vulnerabilities because of a mixed land-use type (some residential areas and forest covers), aquifer media in the form of igneous rocks, steep slopes and deep groundwater.

\subsection{The most influencing factors of groundwater vulnerability}

The most influencing factors of groundwater vulnerability can widely vary across regions. For instance, groundwater recharge and slope are two factors that most significantly affect the groundwater vulnerability in the Daule aquifer [9]. Meanwhile, in the Takelsa aquifer, factors with such influence are groundwater recharge, aquifer media and depths to water tables [17]. The current research has found landuse types to be the most influencing factor aside from depths to water tables. As presented in Table 8, the analysis results of the groundwater vulnerability factors showed that these two parameters had high weight values and high total index values. The total index was adjusted to the classification types of each parameter in the research location.

Table 8. The Susceptibility Index parameters in part of the Klaten District area

\begin{tabular}{clccc}
\hline NO. & Parameters & Rating & $\begin{array}{c}\text { Weight } \\
\text { values }\end{array}$ & $\begin{array}{c}\text { Total } \\
\text { index }\end{array}$ \\
\hline 1. & $\begin{array}{l}\text { Depths to water } \\
\text { table }\end{array}$ & $50-100$ & 0.186 & 57.66 \\
2. & $\begin{array}{l}\text { Groundwater } \\
\text { recharge }\end{array}$ & 90 & 0.212 & 19.08 \\
3. & $\begin{array}{l}\text { Aquifer media } \\
\text { Topography }\end{array}$ & $60-80$ & 0.259 & 36.26 \\
5. & Land use & $50-90$ & 0.121 & 22.99 \\
\end{tabular}

\subsection{Validation to Nitrate}

The vulnerability maps modelled in this study (see Fig. 1 and 2) were validated with the nitrate test results (see Fig.4). Nitrates are associated with the by-products of human activities such as domestic waste disposal, leaching from landfills and excessive use of fertilisers [18]. The intrinsic and specific groundwater vulnerabilities were $19.23 \%$ and $11.54 \%$ accurate based on the validation results. These are considered low because the minimum thresholds for intrinsic and specific vulnerability accuracies are $63 \%$ and $71 \%$, respectively [19]. 


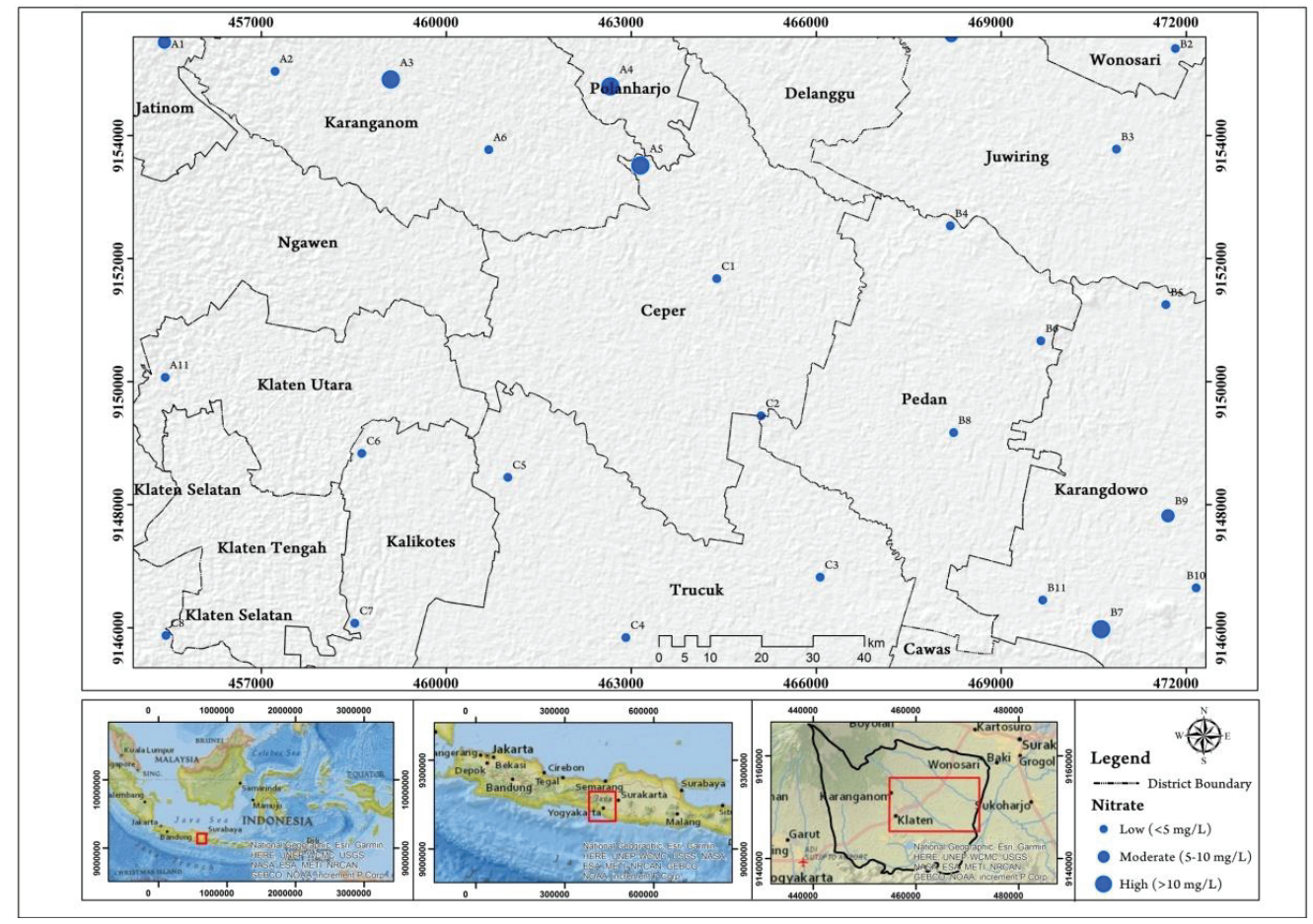

Fig.4. Map of the nitrate test result distribution in part of the Klaten District area.

Groundwater with low nitrate contents $(<5 \mathrm{mg} / \mathrm{L})$ dominated the study area and was found in sub-districts with high vulnerability. This finding does not match with the modelled groundwater vulnerability, which indicates low accuracy. Low nitrate levels can be attributed to the dynamic movement of groundwater and the complex mechanisms with which nitrates enter the groundwater. The amount of nitrate that enters the aquifer zone is also influenced by several factors, including fertiliser application, nitrification, denitrification and transportation by rainwater [20].

The low accuracyis also because some of the parameters are not entirely representative of the research area. This is similar to a previous study in Semarang City, where the groundwater recharge is categorised into $>254 \mathrm{~mm} /$ year [21], although the tropical climate in the city produces a much higher rainfall of up to $>2000 \mathrm{~mm} /$ year. Different climates can cause large differences in rainfall and groundwater recharge; therefore, in this context, the groundwater vulnerability modelled with the SI method has low accuracy.

\section{Conclusion}

The Susceptibility Index measures groundwater vulnerability using five parameters: depth to the water table, groundwater recharge, aquifer media, slope and land use. In part of the Klaten District area, these parameters have varied spatial distribution. The shallowest groundwater is distributed in the middle to the eastern sub-districts, while the deepest is in the north. The groundwater recharge of the entire research area is $>254 \mathrm{~mm} /$ year. The aquifer media are composed of sandstone (in the western sub-districts) and sand and gravel (from the middle to eastern). The Topographys are $<2 \%$ and $2-6 \%$, and some parts of the district are mainly used for irrigated rice fields (distributed in several sub-districts) and dense settlements (in the western and eastern sub-districts). Based on the Susceptibility Index (SI) calculation method, the intrinsic and specific groundwater vulnerabilities are divided into three classes. The areal percentage of the intrinsic groundwater vulnerability is as follows: low (17.83\%, covering the northern and a few sub-districts in the south), moderate (43.93\%, in the north and west) and high (38.24\%, in the east). Meanwhile, the areal percentage of the specific counterparts is as follows: low $(3.04 \%$, covering the northern sub-districts), moderate $(50.53 \%$, the west and north) and high $(46.43 \%$, in the middle to the east). The most influencing factors of groundwater vulnerability in the study area are depths to the water table and land use.

Due to the high groundwater vulnerability in the study area, it is necessary to take protective measures, for example, by:

1. Developing priority areas based on groundwater vulnerability.

2. Formulating waste-related regulations in subdistricts with high groundwater vulnerability

3. Establishing regulations that control groundwater protection 


\section{Acknowledgements}

The authors would like to thank Universitas Gadjah Mada for funding the research through the 2021 Final Project Recognition Grant (Rekognisi Tugas Akhir, RTA). Gratitude is also expressed to the Faculty of Geography,Universitas Gadjah Mada, for supporting and providing the opportunity to carry out this research.

\section{References}

1. Sudarmadji, Perembetan Pencemaran dalam Airtanah pada Akuifer Tak Tertekan di Daerah Lereng Gunungapi Merapi, Research Report, Inter-university Centre for Engineering Sceince (PAU Ilmu Teknik) UGM, Yogyakarta, (1990).

2. Kusuma, K.I, Studi Kerentanan Air Tanah Menggunakan Metode DRASTIC di Urban Area Kota Semarang, Bachelor Thesis, Faculty of Engineering, Diponegoro University, Semarang, (2009).

3. National Research Council, Groundwater Vulnerability Assessment, Contaminant Potential Under Conditions of Uncertainty, National Academy Press, Washington DC, (1993).

4. Riyanto, I. A., \& Widyastuti, M, Kerentanan Intrinsik dan Spesifik Airtanah terhadap Pencemaran di Kecamatan Banjarnegara dan Sekitarnya, Jurnal Bumi Indonesia, 5(4), 1-17, (2016).

5. Prakoso, F. B., Analisis Tingkat Perkembangan Wilayah Kecamatan di Kabupaten Klaten Tahun2005-2015, Bachelor Thesis, Faculty of Geography, Muhammadiyah University of Surakarta, (2018).

6. Prakoso, T. S. (2018). Sawah di Klaten Tak Lagi Subur. Accessed on 1 September 2020, at http://www.koransolo.co/2018/08/28/sawah-diklaten-tak-lagi-subur/

7. Pemerintah Kabupaten Klaten, RTRW Kabupaten Klaten tahun 2011-2031, Perda 11/201, Pemkab Klaten, Klaten, (2011).

8. Putranto, T. T., Ali, R. K., \& Putro, A. B., Studi Kerentanan Airtanah terhadap Pencemaran dengan Menggunakan Metode DRASTIC pada Cekungan Airtanah (CAT) Karanganyar-Boyolali, Provinsi Jawa Tengah, Jurnal Ilmu Lingkungan, 17(1), 158171, (2019).

9. Ribeiro, L., Pindo, J. C., \& Dominguez-Granda, L, Assessment of Groundwater Vulnerability in The Daule Aquifer, Ecuador, Using The Susceptibility Index Method, Science of The Total Environment, 574, 1674-1683, (2017).

10. Hsu, C., Sandford, B, The Delphi Technique: Making Sense of Consensus, Practical Assessment, Research \& Evaluation 12(10), ISSN 1531-7714, (2007).
11. Abdillah, A. dan Adji, T.N., Kajian Kerentanan Airtanah Terhadap Pencemar di Daerah Aliran Sungai Serang, Jurnal Bumi Indonesia, 7(2), 2841, (2018).

12. Jang, W.S., Engel, B., Harbor, J., Theller, L., Aquifer Vulnerability Assessment for Sustainable Groundwater Management using DRASTIC., Water, 9 (792), (2017).

13. Amit, G., Ashwani, K.T., Santosh, D., A GIS based DRASTIC Model for Assessing Groundwater Vulnerability of Katri Watershed, Dhanbad, India. Model, Earth Syst. Environ. 1 (11), 1-14, (2015).

14. Sugianti, K., Mulyadi, D., \& Maria, R, Analisis Kerentanan Pencemaran Air Tanah dengan Pendekatan Metode DRASTIC di Bandung Selatan, Jurnal Lingkungan dan Bencana Geologi, 7(1), 19-33, (2017).

15. Sukadana, I. G., \& Indrastomo, F. D, Kombinasi Pengukuran Radioaktivitas Batuan dan Geofisika dalam Menentukan Akuifer Airtanah Potensial di Desa Sumbermanjing Kulon, Pagak, Malang, Jawa Timur, EKSPLORIUM, 32(2), 125-138, (2011).

16. Ghouili, N., Jarraya-Horriche, F., HamzaouiAzaza, F., Zaghrarni, M. F., Ribeiro, L., \& Zammouri, M., Groundwater Vulnerability Mapping using the Susceptibility Index (SI) Method: Case Study of Takelsa Aquifer, Northeastern Tunisia, Journal of African Earth Sciences, 173, 104035, (2021).

17. Marjuanto, A. A., Putranto, T. T., \&Sugianto, D. N., Mapping of Groundwater Vulnerability Index in the Alluvial Plain of Semarang City Using the Susceptibility Index Method, In E3S Web of Conferences (Vol. 125, p. 01010), EDP Sciences, (2019).

18. Sudaryanto, S., \& Suherman, D., Degradasi Kualitas Airtanah Berdasarkan Kandungan Nitrat di Cekungan Airtanah Jakarta, Riset Geologi dan Pertambangan, 18(2), 61-68, (2008).

19. Putranto, T. T., \& Marjuanto, A. A., Assessment of Contamination Vulnerability of Groundwater using Susceptibility Index Method: Semarang City as Case Study, Journal of Engineering Science and Technology, 16(1), 438-454, (2021).

20. Zhang, D., Li, G., Yang, S., Zhang, X., and Guo, H., Bio-geological Processes of Nitrogen Transport and Transformation in The Aeration Zone and Aquifer, Hydrological Sciences Journal. 54: 316-326, (2009).

21. Abdel madjid, B., \& Omar, S., Assessment of Groundwater Pollution by Nitrates using Intrinsic Vulnerability Methods: A Case Study of The Nil Valley Groundwater (Jijel, North-East Algeria), African Journal of Environmental Science and Technology, 7(10), 949-960, (2013) 